\title{
Studies on Species Diversity of Fruit Flies and Evaluation of Pheromone Lure Longevity in Guava (Psidium guajava L.) cv. Allahabad Safeda
}

\author{
Afreen Tabasum*, Ch. Raja Goud, Veena Joshi, D. Anitha Kumari and A. Bhagwan \\ ${ }^{1}$ Department of Entomology, College of Horticulture, Sri Konda Laxman Telangana State \\ Horticulture University, Rajendranagar, Hyderabad-500030, Telangana, India \\ ${ }^{2}$ Department of Fruit Science, SKLTSHU, Rajendranagar, Hyderabad-500030, \\ Telangana, India \\ ${ }^{3}$ Vegetable Research Station, Rajendranagar, Hyderabad-500030, Telangana, India \\ ${ }^{4}$ Fruit Research Station, Sangareddy, Hyderabad, India \\ *Corresponding author:
}

\section{A B S T R A C T}

Studies were carried out to determine the species diversity of fruit flies and pheromone lure longivity was evaluated in guava orchard cv. Allahabad safeda at Fruit Research

\section{Keywords}

Guava, Fruit flies, Pheromone lure, Fruit fly traps

Article Info

Accepted:

17 December 2018

Available Online:

10 January 2019
Station Sangareddy. Randomized block design was followed for the experiment with 8 treatments and 3 replications. Initially all the traps were loaded with pheromone lure, later the lure was changed from the traps at 30, 35, 40, 45, 50, 55 and 60 days interval. Various parameters such as species diversity of fruit flies, number of fruit fly catches, number of healthy and damaged fruits on the tree, weather data were recorded. Three species of fruit flies viz., Bactrocera correcta, Bactrocera zonata and Gastrozona fasciventris were identified. The number of fruit fly catches were highest in $\mathrm{T}_{1}$ i.e when the lure was changed at 30 days interval, with lowest number of damaged fruits and highest number of healthy fruits against the tree without traps i.e., $\mathrm{T}_{8}$ (Control). When the weather parameters were correlated with number of fruit fly catches and age of the lure it was found that there was positive correlation with maximum temperature, minimum temperature, relative humidity I \& II however there was no correlation with rainfall and negative correlation with wind velocity. Pheromone longevity in the traps was for 30 days.

\section{Introduction}

Fruit flies are considered as the key insects in guava fruit production causing yield losses, quarantine restrictions from importing countries and quality degradation. Thus pheromone traps are used to measure the abundance and distribution of fruit flies in guava. Fruit fly pests are members of the family Tephritidae in the order Diptera and they feed on hundreds of host plants leading to poor commercialization in domestic markets and quarantine restrictions from importing countries. Tephritidae fruit flies are considered a very destructive group of insects that cause enormous economic losses in horticulture, 
especially in a wide variety of fruits, vegetables and flowers. The guava fruit is subjected to attack by several kinds of pests and about 80 species of insects have been recorded on guava, but only few of them have been identified as pest of regular occurrence causing serious damage.

Fruit fly infestations often spread quickly in guava trees which produce sweet smelling with an edible rind and creamy white, yellow or pink flesh. When guava fruits ripe, these emit a pungent, musky odour that attracts fruit flies. Adult female fruit flies have a needle like ovipositor with which they puncture the skin of fruits to lay their eggs in the flesh. Upon contracting the host, fruit flies lay their eggs beneath the skin of fruit and the hatching maggots feed on the flesh, and the resulting damage causes guavas rotting due to microbial decay of the flesh. When the guava fruit is squeezed, the tiny punctures that leak juice from surface indicate the infestation of fruit flies. At first the oviposition marks are difficult to detect but as within one or two days the hatch, oviposition marks appear as a distinct spot with a brownish patch around puncture site.

\section{Materials and Methods}

The fruit fly traps were installed in the guava orchard at Fruit Research Station, Sangareddy. The tip of the traps was tied with help of string on the branches on the guava trees. $15 \mathrm{~cm}$ distance was maintained between the trap and the branch. A total of 21 traps were used which were loaded with the Bado-lure for attracting the male fruit flies present in the orchard at the time of fruiting. The lure was changed at 30, 35, 40, 45, 50, 55 and 60 days interval from the date of installation to determine the longevity of pheromone lure. Randomized block design was followed for the experiment with 8 treatments and 3 replications.

\section{Treatments}

\begin{tabular}{|l|l|}
\hline Treatments & Pheromone lure changed at \\
\hline $\mathbf{T}_{\mathbf{1}}$ & 30 days interval \\
\hline $\mathbf{T}_{\mathbf{2}}$ & 35 days interval \\
\hline $\mathbf{T}_{\mathbf{3}}$ & 40 days interval \\
\hline $\mathbf{T}_{\mathbf{4}}$ & 45 days interval \\
\hline $\mathbf{T}_{\mathbf{5}}$ & 50 days interval \\
\hline $\mathbf{T}_{\mathbf{6}}$ & 55 days interval \\
\hline $\mathbf{T}_{\mathbf{7}}$ & 60 days interval \\
\hline $\mathbf{T}_{\mathbf{8}}$ & Control \\
\hline
\end{tabular}

The lure i.e. methyl eugenol (1, 2-dimethoxy4 [2-propynyl] benzene) was used which was placed inside the fruit fly trap. Observations were recorded at weekly intervals from $42^{\text {nd }}$ to $49^{\text {th }}$ meteorological week.

\section{Different species of fruit flies}

The fruit fly adults that were collected from the fruit fly traps were brought to the
Department of Entomology, College of Horticulture, Rajendranagar and were identified on the basis of their taxonomic characters.

The species which were difficult to be identified were sent to National Bureau of Agricultural Insect Resources (NBAIR), Bengaluru, Karnataka for taxonomic identification. 


\section{Number of male fly catches}

The fruit fly adults were collected from each trap at weekly intervals from $42^{\text {nd }}$ to $49^{\text {th }}$ meteorological week and were counted manually. The average of three trap catches was considered for each treatment.

\section{Correlation of fruit flies with weather parameters}

The weather parameters such as maximum and minimum temperature, relative humidity, rainfall and wind velocity were recorded at weekly intervals from $42^{\text {nd }}$ to $49^{\text {th }}$ meteorological week. The weather data was collected from the Fruit Research Station, Sangareddy to correlate with the adult fly catches and to determine longevity of the pheromone lure.

\section{Results and Discussion}

The catches of fruit flies in 21 methyl eugenol traps installed in guava orchard were recorded at weekly interval from October (42 MW) to December (49 MW) during the year 2017. The trapped flies were studied for species composition. The flies were identified based on taxonomic characters. Three different species of fruit flies were identified and their taxonomic positions are given in Table 1. The results were supported from the reports of different guava growing areas in India which indicated the prevalence of same genera Bactrocera (Shukla and Prasad, 1985; Gupta et al., 1990; Singh, 1997b and Bansode, 2009).

Similar results were reported by the researchers given in the table below

\begin{tabular}{|l|l|}
\hline Fruit fly species & References \\
\hline Bactrocera correcta & $\begin{array}{l}\text { Viraktamath and Babu (2003), Ravikumar and Viraktamath } \\
\text { (2006), Bansode (2009) and Uke (2009). }\end{array}$ \\
\hline $\begin{array}{l}\text { Carrol } \text { et al., (2002), Dale (2002), Gilani } \text { et al., (2002), } \\
\text { Khan } \text { et al., (2005), Patel and Patel (2005), Rajitha and } \\
\text { Viraktamath (2006), Ravikumar and Viraktamath (2006), } \\
\text { Bansode (2009) and Uke (2009). }\end{array}$ \\
\hline
\end{tabular}

The total average flies recorded during the study was 0.45 (Table 2). Highest number of flies was observed, when the pheromone lure was changed at 30 days interval i.e. $\mathrm{T}_{1}$ (1.14). While no flies were observed in $\mathrm{T}_{8}$ i.e. control (without trap).
However there were fluctuations in the population of fruit flies because of changes in the weather conditions. When the lure was changed at 35 days interval there was decline in the population of fruit flies.

Table.1 Different species of fruit flies identified during October-December 2017

\begin{tabular}{|c|c|c|c|c|}
\hline Fruit fly species observed & Family & Sub family & Genus & Species \\
\hline $\begin{array}{c}\text { Bactrocera correcta } \\
\text { (Bezzi) }\end{array}$ & Tephritidae & Dacinae & Bactrocera & correcta \\
\hline $\begin{array}{c}\text { Bactrocera } \text { zonata } \\
\text { (Saunders) }\end{array}$ & Tephritidae & Dacinae & Bactrocera & zonata \\
\hline $\begin{array}{c}\text { Gastrozona fasciventris } \\
\text { (Macquart) }\end{array}$ & Tephritidae & Dacinae & Gastrozona & fasciventris \\
\hline
\end{tabular}


Table.2 Number of male fly catches recorded at weekly interval during October to December, 2017

\begin{tabular}{|c|c|c|c|c|c|c|c|c|}
\hline Treatments & \multicolumn{8}{|c|}{ Standard week } \\
\hline $\begin{array}{c}\mathbf{T}_{2} \text { (lure changed at } 35 \text { days } \\
\text { interval) }\end{array}$ & 0.33 & 0.66 & 1.33 & 0.33 & 0.33 & 0.00 & 0.00 & 0.00 \\
\hline $\begin{array}{c}\mathrm{T}_{4} \text { (lure changed at } 45 \text { days } \\
\text { interval) }\end{array}$ & 1.66 & 1.00 & 0.66 & 0.34 & 0.00 & 0.33 & 0.00 & 0.00 \\
\hline $\begin{array}{c}\mathrm{T}_{5} \text { (lure changed at } 50 \text { days } \\
\text { interval) }\end{array}$ & 1.66 & 0.66 & 0.33 & 0.00 & 0.17 & 0.00 & 0.00 & 0.00 \\
\hline $\begin{array}{c}\mathbf{T}_{6} \text { (lure changed at } 55 \text { days } \\
\text { interval) }\end{array}$ & 0.66 & 1.66 & 0.00 & 1.00 & 0.66 & 0.00 & 0.00 & 0.00 \\
\hline $\mathrm{SE}(\mathrm{m}) \pm$ & 0.011 & 0.010 & 0.008 & 0.008 & 0.007 & 0.004 & 0.001 & 0.001 \\
\hline C.D at $5 \%$ & 0.035 & 0.032 & 0.024 & 0.023 & 0.021 & 0.013 & 0.004 & 0.004 \\
\hline
\end{tabular}


Table.3 Correlation between weather parameters and fruit flies at weekly intervals

\begin{tabular}{|c|c|c|c|c|c|c|c|c|}
\hline $\begin{array}{c}\text { Weather } \\
\text { parameters }\end{array}$ & $\mathbf{T}_{\mathbf{1}}$ & $\mathbf{T}_{\mathbf{2}}$ & $\mathbf{T}_{\mathbf{3}}$ & $\mathbf{T}_{\mathbf{4}}$ & $\mathbf{T}_{\mathbf{5}}$ & $\mathbf{T}_{\mathbf{6}}$ & $\mathbf{T}_{\mathbf{7}}$ & $\mathbf{T}_{\mathbf{8}}$ \\
\hline $\begin{array}{c}\text { Maximum } \\
\text { temperature }\end{array}$ & 0.779 & 0.544 & 0.702 & 0.868 & 0.720 & 0.636 & 0.486 \\
\hline $\begin{array}{c}\text { Minimum } \\
\text { temperature }\end{array}$ & 0.507 & 0.277 & 0.622 & 0.847 & 0.879 & 0.631 & 0.502 \\
\hline $\begin{array}{c}\text { Relative } \\
\text { humidity I }\end{array}$ & 0.688 & 0.581 & 0.737 & 0.692 & 0.584 & 0.568 & 0.000 \\
\hline $\begin{array}{c}\text { Relative } \\
\text { humidity II }\end{array}$ & 0.615 & 0.439 & 0.512 & 0.974 & 0.969 & 0.382 & 0.704 \\
\hline $\begin{array}{c}\text { Rainfall } \\
\text { Wind }\end{array}$ & 0.000 & -0.626 & -0.000 & 0.000 & 0.000 & 0.000 & 0.000 & 0.000 \\
\hline velocity & & -0.780 & -0.825 & -0.772 & -0.767 & -0.374 \\
\hline
\end{tabular}


Peak activity of flies was observed in the $T_{1}$ i.e. when the lure was changed at 30 days interval. These results coincided with work on population dynamics of fruit flies reported in Gujarat by Dale (2002) and Bansode (2009) and Karnataka (Rajitha and Viraktamath, 2006).

From the studies of influence of weather parameter on overall population, it may be concluded that fly population was directly influenced by maximum and minimum temperature, $\mathrm{RH}$ I and RH II, whereas no correlation with rainfall and negative correlation with wind velocity.

The correlation data have been presented in Table 3. This indicates that increase in temperature (maximum and minimum), relative humidity (I and II) increases the fruit fly population and vice versa while decrease in wind velocity increases the fly population and vice versa. The findings are in confirmation with the reports of Sarada et al., (2001b), Dale (2002), Bansode (2009).

It can be concluded that three species of fruit flies viz., Bactrocera correcta, Bactrocera zonata and Gastrozona fasciventris were identified in the guava ecosystem and pheromone longevity in the traps was for 30 days.

\section{References}

Bansode, G.M., Patel, Z.P. and Shinde, C.U. 2009. Comparative biology of Bactrocera dorsalis (Hendel) on major fruit crops of Gujarat. Pestology, 33(11): 21-24.

Carrol, L.E., White, J.M., Friedbery, A.S., Morrbom, A.L., Dalliwitz, M.J. and Thompson, F.C. 2002. Pest fruit flies of the world. Description, Illustrations, Identifications and Information Retrieval. Version 8th.
Dale, N.S. 2002. Studies on biology of Bactrocera zonata (Saunders) and management of fruit flies in mango orchards. M.Sc. (Agri.) Thesis (Unpublished) submitted to Gujarat Agricultural University, S.K. Nagar.

Gilani, W.A., Tariq, B. and Mohammad, I. 2002. Studies on population dynamics of fruit flies (Diptera: Tephritidae) in guava and nectrin orchard in Islamabad. Pakistan Journal of Biological Science. 5(4): 452-454.

Gupta, D., Verma, A.K. and Bhalla, O.P. 1990. Population of fruit flies (Dacus zonatus and $D$. dorsalis) infesting fruit crops in North-Western Himalayan region. Indian Journal of Agricultural Science, 60(7): 471-474.

Khan, M.A., Muhammad, A., Waessem, A. and Lee, L.L. 2005. Management of fruit flies of the most perishable fruit. Journal of Entomological Research, 35(2): 79-84.

Patel, Z.P. and Patel, M.R. 2005. Up-date on work done in Integrated Management of fruit flies in India. Presented in Workshop at "The Magestic, Goa", 6-7 Oct. pp. 22.

Rajitha, A.R. and Viraktamath, S. 2006. Monitoring of fruit flies in guava orchard at Dharwad, Karnataka. Journal of Agricultural Science, 19(1): 145-149.

Ravikumar, Ch. and Viraktmath, S. 2006. Influence of weather parameters on fruit fly trap catches in Dharwad, Karnataka. Pest Management in Horticultural Ecosystem, 12(2): 143-151.

Sarada, G., Maheshwari, T.U. and Purushotham, K. 2001b. Seasonal Incidence and population fluctuation of fruit flies in mango and guava. Indian Journal of Entomology. 63(3): 272-276.

Shukla, R.P. and Prasad, V.G. 1985. Population fluctuation of Oriental fruit fly, $D$. dorsalis in relation to host and abiotic factors. Tropical Pest 
Management, 31(4): 273-275.

Singh, S.P. 1997b. Fruit flies and their management. Indian Horticulture, 42(1): 35-37.

Uke, N.S. 2009. Studies on species composition and losses caused by guava fruit fly, Bactrocera spp. in Pune Region. M.Sc. (Agri.) Thesis
(Unpublished) submitted to Mahatma Phule Krishi Vidyapeeth, Rahuri (India).

Viraktamath, S. and Babu, S. 2003. Species composition and population dynamics of fruit flies (Diptera: Tephritidae) on guava. South Indian Horticulture, 52(16): 317-323.

\section{How to cite this article:}

Afreen Tabasum, Ch. Raja Goud, Veena Joshi, D. Anitha Kumari and Bhagwan, A. 2019. Studies on Species Diversity of Fruit Flies and Evaluation of Pheromone Lure Longevity in Guava (Psidium guajava L.) cv. Allahabad Safeda. Int.J.Curr.Microbiol.App.Sci. 8(01): 26792685. doi: https://doi.org/10.20546/ijcmas.2019.801.282 